\section{Buchrezension zu: Die Reise unserer Gene}

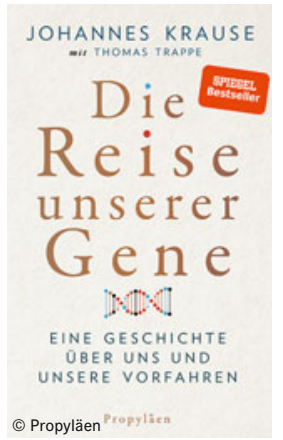

Die Reise unserer Gene Eine Geschichte über uns und unsere Vorfahren

Johannes Krause mit

Thomas Trappe

288 S., Propyläen, 3. Aufl., 2019.

HC mit $S U, 22,00 €$.

ISBN: 9783549100028

Auch als E-Book erhältlich

DOI: 10.1007/s12268-020-1384-4

(C) Springer-Verlag GmbH 2020

Die Reise unserer Gene beschreibt die wichtigsten Wanderungsbewegungen von Menschen in den letzten 600.000 Jahren anhand von DNA-Analysen. Der Erstautor, Johannes Krause, war an vielen dieser Arbeiten selbst beteiligt, zuerst als Postdoc im Max-Planck-Institut für evolutionäre Anthropologie in Leipzig und jetzt als Direktor am Max-PlanckInstitut für Menschheitsgeschichte in Jena. Deswegen schafft er es auch, die technischen Schwierigkeiten der DNA-Analyse aus fossilen Fundstücken sehr anschaulich zu beschreiben und aus den Unterschieden der DNA-Sequenzen in den verschiedenen Fundstücken die variierenden Wanderungsbewegungen der Menschen vor allem in Europa darzustellen - von den Neandertalern und den Denisova-Menschen, später von den Jägern und Sammlern, den Ackerbauern und Viehzüchtern und dem Einbruch der Reitervölker aus der Pontischen Steppe.

Interessante Aspekte sind dabei auch Fragen, wie die verschiedenen Populationen in der jeweili- gen Zeit miteinander umgegangen sind: Gab es kriegerische Auseinandersetzungen sowie Verletzungen, und welcher Population gehörten die Opfer an? Oder kam es zu Vermischungen der Populationen, und wie war dann später der Anteil der mitochondrialen DNA, die durch Frauen übertragen wird, und des Y-Chromosoms, das durch Männer weitergegeben wird? Eine Vielzahl von spannenden Fragen, die Johannes Krause eingängig beantwortet.

Zur besseren Illustration der Wanderungsbewegungen beginnt jedes Kapitel mit einer Karte; auBerdem gibt es am Ende des Buches ein Literaturverzeichnis. Zusätzlich gibt der Autor auch Hinweise auf Krankheitserreger (z. B. die Pest), deren DNA an den Skeletten noch nachgewiesen werden kann. Zusammen mit Hinweisen auf kulturelle Entwicklungen wie Schrift und Sprache ergibt das insgesamt ein tolles Buch. Wenn da nicht eine andere Sache wäre: Der Autor versucht, Wissenschaft und die aktuelle Debatte über Migration zusammenzubringen. Der „erhobene Zeigefinger" des Max-Planck-Direktors an einigen Stellen des Buches wirkt auf mich nicht nur überflüssig, sondern störend. Jeder Leser kann das auf seinem eigenen Hintergrund sicherlich selbst bewerten. Und ein Zweites hat mich beim Lesen etwas irritiert: das Hervorheben der eigenen Leistungen bei der Analyse einzelner Aspekte. Ich hätte mir bei der Darstellung etwas mehr Abstraktion gewünscht. Dennoch: Ich habe das Buch mit Gewinn gelesen und bin auf neue Entwicklungen auf dem Gebiet der Paläo- und Archäogenetik gespannt!

Jochen Graw, Unterschleißheim, jochen.graw@tum.de 